\title{
Magnitude and factors associated with anemia among pregnant women attending antenatal care at st. Paul's Hospital Millennium Medical college, Addis Ababa, Ethiopia, July, 2019
}

Desta Samuel Umuro ( $\nabla$ samueldesta6@gmail.com )

University College London Hospitals NHS Foundation Trust

Yared Lasebew Asres

St. Paul's Hospital Millenium Medical College

Gezahegn Mamo Muluneh

St. Paul's Hospital Millenium Medical College

Research article

Keywords: Magnitude, Anemia, Pregnant women

Posted Date: August 15th, 2019

DOl: https://doi.org/10.21203/rs.2.13046/v1

License: (c) (i) This work is licensed under a Creative Commons Attribution 4.0 International License.

Read Full License 


\section{Abstract}

Background: This study aimed to assess magnitude and factors associated with anemia among pregnant women attending antenatal clinic at St. Paul's Hospital Millennium Medical College, Addis Ababa, Ethiopia. Methods: Institution based cross sectional study design was conducted from December 1, 2018 to January 15, 2019 on 405 pregnant women attending antenatal clinic. All pregnant women visiting the Antenatal care clinic during the study period and who fulfilled the eligibility criteria were included in the study. Secondary data was collected from clients register and personal files on hemoglobin, HIV, stool, and other variables. Descriptive statistics was used to analysis some variables by using SPSS. Logistic regression was carried out to identify factors associated with anemia in pregnancy. Adjusted odds ratio with their $95 \%$ of confidence interval and $p<0.05$ are consider to have significant association. Results: The magnitude of Anemia in pregnant women in this study was $19.8 \%,(95 \% \mathrm{Cl}$ 16.00-23.70). HIV infection (AOR=6.12(95\% Cl 2.19, 17.08) parasitic infestation (AOR= $11.88(95 \% \mathrm{Cl}$ $5.60,25.20)$ and history of not taking fruit after meal during pregnancy ( $A O R=3.12(95 \% \mathrm{Cl} 1.72,5.67)$ were the major determinants of anemia. Conclusion: This study showed that the magnitude of anemia among pregnant women was high especially at third trimester. Living with HIV /AIDS, parasitic infestation and no history of taking fruits after meal were the main factors.

Key words: Magnitude, Anemia, Pregnant women

\section{Background}

Anemia is a decrease in the oxygen carrying capacity of the blood. It can arise if the hemoglobin $(\mathrm{Hgb})$ concentration of the red blood cells (RBCs) or the packed cell volume of RBCs (PCV) is below the lower limit of the reference interval for the individual's age, gender, geographical location, and physiological status (1).The World Health Organization (WHO) has suggested that anemia is present in pregnancy when $\mathrm{Hgb}$ level is $<11 \mathrm{~g} / \mathrm{dl}$ (during $1^{\text {st }}$ and $3^{\text {rd }}$ trimester of pregnancy and hemoglobin level below 10.5 $\mathrm{g} / \mathrm{dl}$ during $2^{\text {nd }}$ trimester of pregnancy. It also classified anemia in pregnancy as mild $(10.0-10.9 \mathrm{~g} / \mathrm{dl})$, moderate $(7.09 .9 \mathrm{~g} / \mathrm{dl})$, and severe (lowerthan $7.0 \mathrm{~g} / \mathrm{dl})$ based on the level of hemoglobin concentration (2). Anemia is a major health problem that affects $25 \%$ to $50 \%$ of the population of the world. It is estimated that $41.8 \%$ of pregnant women worldwide are anemic(3). The WHO estimates the magnitude of anemia to be $17.5 \%-40.5 \%$ in women of reproductive age Studies show that anemia in pregnancy is globally common but Africa and Asia bear the greatest burden. In Africa and South East Asia, the magnitude is estimated at $57.1 \%$ and $48.2 \%$ respectively. Anemia in pregnancy is associated with increased rates of maternal and perinatal mortality, premature delivery, low birth weight and other adverse outcomes(4). According to literatures the predisposing factors for anemia in pregnant women include, socioeconomic status, Parasitic Infestation (Malaria and Helminthes), and obstetric condition(5).The cutoff point suggested by United States Center for Diseases Control to determine anemia is when a hemoglobin level is less than $11 \mathrm{~g} / \mathrm{dl}$ in the first and third trimester and less than $10.5 \mathrm{~g} / \mathrm{dl}$ in the second trimester of pregnancy(6). The World Health Organization (WHO) defined anemia as hemoglobin concentration below $11 \mathrm{~g} / \mathrm{dl}$ in pregnancy and will classify as mild, moderate and severe(7). The estimated global magnitude is 
$42 \%$ in pregnant women and it is a major cause of maternal mortality(8). In Africa $57.1 \%$ of the pregnant women were Anemic, more over anemia in pregnant women is a sever public health problem, in Ethiopia $29 \%$ and also different studies were conducted on magnitude of anemia among pregnant women, the magnitude range being from $9.7 \%$ in North Shoa Zone to $56.8 \%$ in Eastern Ethiopia (9). Studying the specific etiology and magnitude of anemia in a given setting and population group is very important to prevent or treat anemia(10). However, there is very little data available in the study area. Therefore, this study is aimed to assess the magnitude and factors associated with anemia in pregnant women at St. Paul's Hospital Millennium Medical College, Addis Ababa, Ethiopia.

\section{Methods}

The study was conducted at St. Paul's Hospital Millennium Medical College, one of the federal hospitals of Addis Ababa, located in Gulele sub city. It is one of the referral hospitals directly under the federal Ministry of health and a teaching hospital for medical students, postgraduate students (field Epidemiologists) and nurse specialties (operation theatre nurses, emergency and ICU nurses) in the College. According to the report obtained from human resource department, the hospital gives services to an estimated 200,000 people annually who are referred from all corners of the Country. Hospital offers full range of comprehensive health services i.e. medical, surgical, pediatric, obstetrics and gynecology and basic emergency services. The Maternity unit comprises of labor ward, operating theatre, antenatal and postnatal wards and a new born unit. Average monthly attendance for ANC is about 280 pregnant mothers with around 80 new clients every month and an average of 20 clients per week. Hence the site is suitable for the study, because of the large numbers of women seen in this facility.

\section{Study Design}

Institution based cross sectional study design was conducted.

\section{Study Population}

The study population was all pregnant women who came for antenatal care follow up to the hospital.

\section{Data Collection Tools \& Procedures}

The data was collected using structured questionnaire that fulfilled the objective of the study, adopted through reviewing of different literatures and previous similar studies. Data was collected form 405 respondents by face to face interview. Clinical evaluation of laboratory results was also considered from ANC charts. Three data collectors (midwifery nurses) involved in the data collection. They were given one day training on the administration of the questionnaire and clinical evaluation of client's cards. They were also involved in the pretesting of the questionnaire. The questionnaires were examined for clarity, ambiguity, time taken to fill it out and analyzability. Appropriate adjustments were made to keep quality of data. 
After clients received the routine ANC services, the data collectors provide information for the clients about the study, its objectives, risks and benefits and consent was taken from them. Medical records of the study participants were also reviewed for the results of routine laboratory tests (Hgb level, Stool examination, VDRL, HIV test etc). The respondents were interviewed in a private study room. The interviews were conducted in a safe, secure and confidential environment. From the anti natal cards, any respondent found to have hemoglobin level of less than $11 \mathrm{~g} / \mathrm{dl}$ was linked to the physician in charge for further care and treatment after completion of the interview. Double participant recruitment was prevented by enquiring from the client if they had completed the interview before.

\section{Data Analysis}

During data entry attention was given to check errors and data cleaning considered. Data entry and clearing was done using Epi info version 7.2.2.6 and data was exported for analysis to Statistical Packages for Social Sciences (SPSS) version 23. During analysis, frequencies of the different variables determined and results were presented in texts, tables and graphs using summery measures such as percentages, mean and median.

For categorical variables, frequency, percentage and descriptive summaries were used to describe the study variables using univariate analysis.

Logistic regression was carried out to identify factory associated with Anemia. Independent variables found to be significant in the simple binary logistic regression analysis at a cut point of $p$-value $<0.2$ with $95 \%$ of confidence interval were included in the multiple binary logistic regression models.

The effect of each independent variable on the anemia was assessed by controlling for the possible confounders adjusted odds ratios (AOR) with their $95 \%$ confidence intervals and p-value of less than 0.05 were considered to have significant association between anemia and the explanatory variables.

\section{Results}

\section{Magnitude of anemia in pregnant women}

This study showed that the overall magnitude of anemia among the study participants was $19.8 \%$ (Cl; 16.00-23.70). Among the participants, $13.2 \%$ had mild anemia, $4.4 \%$ had moderate anemia and $2.2 \%$ had severe anemia. The rest $80.4 \%$ didn't develop anemia.

\section{Factors associated with anemia in pregnant women}

Bivariate logistic regression was used to test association between age, knowledge, educational status, income, occupation, marital status, family size, parasitic infection, HIV infection, gravid, knowledge, history of abortion, history of alcohol and smoking and history of bleeding. However, only gravidity, history of bleeding in current pregnancy, HIV/AIDS, parasitic infection and history of no taking fruit after meal were significantly associated with anemia. 
In multivariate analysis, HIV, parasitic infection and history of not taking fruits after meal were significantly associated with anemia.

HIV infected individuals were six times more likely to be anemic than those none infected (AOR=6.126 $(95 \% \mathrm{Cl} 2.197,17.084)$. The odds of having anemia among in those having parasitic infection were nearly twelve times higher than those who are free from parasitic infections (AOR=11.88 $(95 \% \mathrm{Cl}$ $5.606,25.204)$ ). The habit of do not taking fruits after meal was also statistically associatiated with anemia. Pregnant women that do not have the habit of taking fruit after meal were three times more likely to have anemia $(A O R=3.128(95 \% \mathrm{Cl} 1.723,5.679))$ than those who have the habit. 
Table 1; The bivariate analysis on obstetrics and medical factors of anemia among pregnant women, St. Paul's Hospital Millennium Medical college Addis Ababa, Ethiopia, 2019.

\begin{tabular}{|c|c|c|c|c|}
\hline \multirow{2}{*}{\multicolumn{2}{|c|}{ Explanatory variables }} & \multicolumn{2}{|c|}{ Anemia } & \multirow{3}{*}{$\begin{array}{l}\text { COR }(95 \% \mathrm{Cl}) \\
1.148(0.492,2.679)\end{array}$} \\
\hline & & \multirow{2}{*}{$\begin{array}{l}\text { Yes } \\
8(10.0)\end{array}$} & \multirow{2}{*}{$\begin{array}{l}\text { No } \\
25(7.7)\end{array}$} & \\
\hline Pregnancy status & $1^{\text {st }}$ Trimester & & & \\
\hline & $2^{\text {nd }}$ Triminster & 14(17.5) & $92(28.3)$ & $0.546(0.290,1.028)$ \\
\hline & $3^{\text {rd }}$ Trimester & $58(72.5)$ & $208(64.0)$ & 1 \\
\hline \multirow[t]{2}{*}{ Gravidity } & Prime-gravid & $54(67.5)$ & $201(61.8)$ & 1 \\
\hline & Multi gravid & $26(32.5)$ & 124(38.2) & $1.281 \quad(0.763,2.152)$ \\
\hline \multirow[t]{2}{*}{ Sero status } & HIV +ve & $15(18.8)$ & $9(2.8)$ & $8.103(3.400,19.310)$ \\
\hline & HIV - ve & $65(81.2)$ & $316(97.2)$ & 1 \\
\hline \multirow[b]{2}{*}{ Syphilis } & VDRL+ve & $4(5.0)$ & $6(1.8)$ & $2.798(0.771,10.162)$ \\
\hline & VDRL-ve & $76(95.0)$ & $319(98.2)$ & 1 \\
\hline \multirow[t]{2}{*}{ History of bleeding } & Yes & $10(12.5)$ & $18(5.5)$ & $2.437 \quad(1.078,5.507)$ \\
\hline & No & $70(87.5)$ & $307(94.5)$ & 1 \\
\hline \multirow{2}{*}{ Parasitic infection } & Yes & $33(41.2)$ & $14(4.3)$ & $15.597(7.774,31.294)$ \\
\hline & No & $47(58.8)$ & $311(95.7)$ & 1 \\
\hline \multirow[t]{2}{*}{ Chronic diseases } & Yes & $18(22.5)$ & $28(8.6)$ & $3.079 \quad\left(\begin{array}{lll}1.604 & 5.913\end{array}\right)$ \\
\hline & No & $62(77.5)$ & 297(91.4) & 1 \\
\hline \multirow[t]{2}{*}{ History of Abortion } & Yes & 18(22.5) & $47(14.5)$ & $\left.\begin{array}{lll}1.717 & (0.934 & 3.157\end{array}\right)$ \\
\hline & No & $62(77.5)$ & $278(85.5)$ & 1 \\
\hline \multirow{2}{*}{$\begin{array}{l}\text { Awareness } \\
\text { for anemia }\end{array}$} & Yes & $24(30.0)$ & $96(29.5)$ & 1 \\
\hline & No & $56(70.0)$ & $229(70.5)$ & $0.978(0.573,1.669)$ \\
\hline \multirow[t]{2}{*}{ Fruit intake } & Yes & $28(35.0)$ & $212(65.2)$ & 1 \\
\hline & No & $52(65.0)$ & $113(34.8)$ & $3.484 \quad(2.086 \quad 5.820)$ \\
\hline \multirow[t]{2}{*}{ Taking coffee or tea after meal } & Yes & $44(55.0)$ & $265(81.5)$ & $0.277 \quad(0.164 \quad-0.466)$ \\
\hline & No & $36(45.0)$ & $60(18.5)$ & 1 \\
\hline \multirow[t]{2}{*}{ Iron tablet intake } & Yes & $59(73.8)$ & $216(66.5)$ & 1 \\
\hline & No & $21(26.2)$ & $109(33.5)$ & $0.705 \quad(0.407-1.221)$ \\
\hline \multirow[t]{2}{*}{ Alcohol consumption } & Yes & $10(12.5)$ & $13(4.0)$ & $0.292(0.123,0.692)$ \\
\hline & No & $70(87.5)$ & $312(96.0)$ & 1 \\
\hline
\end{tabular}

Table2: Bivariate and multivariate analysis of factors associated with anemia in pregnant women, St. Paul's Hospital Millennium Medical College, Addis Ababa, Ethiopia, 2019 


\begin{tabular}{|c|c|c|c|c|c|}
\hline \multirow{2}{*}{\multicolumn{2}{|c|}{ Explanatory variables }} & \multicolumn{2}{|l|}{ Anemia } & \multirow{3}{*}{$\begin{array}{l}\text { COR }(95 \% \mathrm{Cl}) \\
15.597(7.774,31.294)\end{array}$} & \multirow[t]{2}{*}{ AOR $(95 \% \mathrm{Cl})$} \\
\hline & & Yes & No & & \\
\hline \multirow[t]{2}{*}{$\begin{array}{l}\text { Parasitic } \\
\text { infection }\end{array}$} & Yes & $33(41.2)$ & $14(4.3)$ & & $\begin{array}{l}11.886(5.606 \\
25.204)^{\star \star}\end{array}$ \\
\hline & No & $47(58.8)$ & $311(95.7)$ & 1 & 1 \\
\hline \multirow[t]{2}{*}{ Sero status } & $\begin{array}{l}\text { HIV } \\
\text { +ve }\end{array}$ & $15(18.8)$ & $9(2.8)$ & $8.103(3.400,19.310)$ & $\begin{array}{l}6.126 \quad(2.197 \\
, 17.084)^{\star}\end{array}$ \\
\hline & $\begin{array}{l}\text { HIV - } \\
\text { ve }\end{array}$ & $65(81.2)$ & $316(97.2)$ & 1 & 1 \\
\hline \multirow[t]{2}{*}{ Fruit intake } & Yes & $52(65.0)$ & 113(34.8) & 1 & 1 \\
\hline & No & $28(35.0)$ & $212(65.2)$ & $\begin{array}{l}3.484 \\
5.820)\end{array}$ & $\begin{array}{l}3.128 \quad(1.723 \\
5.679)^{\star \star \star}\end{array}$ \\
\hline \multirow[t]{2}{*}{$\begin{array}{l}\text { History of } \\
\text { bleeding }\end{array}$} & Yes & $10(12.5)$ & $18(5.5)$ & $\begin{array}{l}2.437 \\
5.507)\end{array} \quad$ (1.078, & $1.378 \quad\left(\begin{array}{lll}0.463 & 4.101\end{array}\right)$ \\
\hline & No & $70(87.5)$ & $307(94.5)$ & 1 & 1 \\
\hline \multirow[t]{2}{*}{ Chronic diseases } & Yes & 18(22.5) & $28(8.6)$ & $\begin{array}{l}3.079 \quad(1.604 \\
5.913)\end{array}$ & $\begin{array}{lll}1.379 & 0.565 & 3.368\end{array}$ \\
\hline & No & $62(77.5)$ & 297(91.4) & 1 & 1 \\
\hline \multirow[t]{4}{*}{$\begin{array}{l}\text { Age of } \\
\text { respondent }\end{array}$} & $<24$ & $\begin{array}{l}17 \\
(21.3)\end{array}$ & 68 (20.9) & 1 & 1 \\
\hline & $25-29$ & $\begin{array}{l}28 \\
(35.0)\end{array}$ & $150(46.2)$ & $\begin{array}{l}0.747 \\
(0.383,1.455)\end{array}$ & $0.807 \quad\left(\begin{array}{lll}0.365 & 1.783\end{array}\right)$ \\
\hline & $30-34$ & $\begin{array}{l}17 \\
(21.3)\end{array}$ & $78(24.0)$ & $\begin{array}{l}0.872 \\
(0.413,1.840)\end{array}$ & $1.014 \quad(0.424,2.426)$ \\
\hline & $\geq 35$ & $18(22.5)$ & $29(8.9)$ & $\begin{array}{l}2.483 \\
(1.124,5.485)\end{array}$ & $\left.\begin{array}{lll}2.128 & (0.792 & 5.719\end{array}\right)$ \\
\hline
\end{tabular}

\section{Discussion}

This study showed that the overall magnitude of anemia among the study participants was $19.8 \%$ (95\% $\mathrm{Cl}$ 16.00-23.70). This result is Similar with the findings from previous studies conducted in, Gondar $(16.6 \%)(11)$, Shire,Tigray (16.3\%)(12),MizanTepi (23.5\%)(13) and Nigeria (16.8\%)(14). It is considerably lower than the national average $(29.1 \%)(15)$ and other previous study reports from North West Tigray (36.1\%)(16), Ilu Abba Bora Zone, South West Ethiopia: (31.5\% (17),west Arsi (36.6\%,)(18) Gilegle Gibe $(53.9 \%),(19)$ and southern Ethiopia 65\%(20).

The possible reasons for the difference may be resulted from geographical variation of factors across different areas. In addition, lower magnitude can be attributed to gradual improvement of life style and living standards, using the iron supplementation ordered by the physician during follow up.

This study finding showed a slightly higher magnitude than studies conducted in Hawassa (15.3\%) (21) ,Tikur Anbesa Specialized Hospital (14.1\%)(22) , Adama town (11.3\%)(23), North Shoa zone (9.7\%)(9) 
and Adigrat General Hospital 7.9\%(24). This variation might be due to differences in sample size, study design, study period, study setting, and socio-demographic characteristics.

This study also showed that being HIV positive, parasitic infestation and women with history of not taking fruits as significant determinants of anemia during pregnancy.

Pregnant women having parasitic infestation were nearly 12 times AOR $=11.886(95 \% \mathrm{Cl} 5.606,25.204)$ more likely to be anemic than their counterparts. This finding is consistent with studies conducted in Gondar(25), Shire(12), Adigrat (24), and North Shoa (9). This might be due to the reason that parasites attach and injure upper intestinal mucosa and ingest blood. This brings gastrointestinal blood loss and induces depletion of iron, folic acid, and vitamin B12 that ultimately results in anemia (26).

This study also showed that HIV positive pregnant women were six times (AOR=6.126 $(95 \% \mathrm{Cl} 2.197$, 17.084) more likely to develop anemia during pregnancy than those who are not infected

with HIV. Studies conducted in Mizan (13),Gondar (11) and Shire (12) showed a similar association between anemia and HIV infection. This increased prevalence of anemia among HIV seropositive pregnant women might be explained by the fact that HIV infection is associated with lower serum folate, vitaminB12, and ferritin in pregnancy. In addition, Anemia in HIV/AIDS patients may arise from a number of causes, including deregulation of the host immune system leading to destruction or inhibition of hematopoietic cells (27).

Women who did not have the habit of taking fruits were found to be three times (AOR $3.128(95 \% \mathrm{Cl}$ $1.723,5.679)$ more likely be anemic than those who have the habit of taking fruits. This finding is similar with a study conducted in South West Arisi zone(18). This might be due to the fact that taking fruits before and after meal may facilitate iron absorption in gastro intestinal system. good knowledge about basic nutrients and adequate well balanced diet usually resulting in positive dietary practices which are important determinants of optimum health (28).

\section{Conclusion}

The magnitude of anemia among pregnant women was high especially at third trimester. Living with HIV/AIDS, parasitic infestations and no history of taking fruit after meal were the main predictors of maternal anemia during pregnancy. It is expected that this study will be used to obtaining information relating to anemia in pregnancy and will help in providing information relating to anemia magnitude and associated factors in the hospital to the hospital administration, health care workers and decision makers

\section{List Of Abbreviations}

ANC Antenatal care

EDHS Ethiopia demographic health system 


$\begin{array}{ll}\text { HGB } & \text { Hemoglobin } \\ \text { HCT } & \text { Hematocrit } \\ \text { IDA } & \text { Iron deficiency anemia } \\ \text { MCV } & \text { Mean Corpuscular Volume } \\ \text { MOH } & \text { Ministry of health } \\ \text { SPHMMC } & \text { Saint Paul's hospital millennium medical college } \\ \text { UNDP } & \text { United Nations Development Programme } \\ \text { UNICEF } & \text { United Nations Emergency Children's Fund } \\ \text { WHO } & \text { World Health Organization }\end{array}$

\section{Declarations}

\section{Ethics approval and consent to participate}

Ethical clearance and written permission was obtained from St. Paul's Hospital Millennium Medical College Institutional Research Board. Informed consent was obtained from each study participants. Confidentiality and privacy of participants was ensured at all levels throughout the study by keeping the data and records in a safe place.

\section{Consent for publication}

All authors agreed and agreed for publication

\section{Competing interests}

There are no competing interests among authors

\section{Funding}

This research was funded by St. Paul's Hospital Millennium Medical College.

\section{Authors' contributions}

DS designed the study, collected the required data and plays a vital role in acquisition of funding, write up the draft thesis, analysis and interpretation of the research. YL participated in analysis and interpretation of the research, write up and critical revision of the manuscript and general supervision of the research 
group. GM participated in data collection, revision and analysis of the research and manuscript. All authors reviewed and approved the final manuscript.

\section{Acknowledgement}

The authors are grateful to the study participants. Our special thanks go to St. Paul's Hospital Millennium medical College for their financial support to this study.

\section{References}

1. WHO. M.L.Turgeon, Clinical Hematology: Theory and procedure, Wilkins, a Walters Kluters Kluwer business, Philadelphia. 2015;5th edition.

2. World Health Organization, editor. WHO recommendations on antenatal care for a positive pregnancy experience. Geneva: World Health Organization; 2016. 152 p.

3. World Health Organization (WHO): The database on anemia includes data by country on prevalence of anemia and mean hemoglobin. Geneva, Switzerland: WHO; 2014. 2014;04/2014.

4. van den. Van den RB, B.N., Etiology of anemia in pregnancy in South Malawi. Am J ClinNutr 2015; in South Malawi. Am J ClinNutr; 72: 247S-256S.. 2010: p. 72: 247S-256S. 2015;

5. Aluka C, A.A., Kamanu Cl, Feyi-Waboso PA,5 Amadi AN, O.S., Kamanu Cl, NjokuNjoku OO, Aluka C, Study).

6. World Health Organization: Report of WHO group of experts on nutritional anemia. Technical report series.Geneva, WHO, 2014.

7. Centers for Diseases Control: Criteria for anemia in children and childbearing-aged women. MMWR 2012; 38:400- 404.

8. M. Alem, B. Enawgaw, A. Gelaw, T. Kena, M. Seid, and Y. Olkeba, "Prevalence of anemia and associated risk factors among pregnant women attending antenatal care in Azezo Health Center Gondar town, Northwest Ethiopia," Journal of InterdisciplinaryHistopathology,vol.1,no.3,pp.137$144,2013$.

9. Mekonnen FA, Ambaw YA, Neri GT. Socio-economic determinants of anemia in pregnancy in North Shoa Zone, Ethiopia. Ghose B, editor. PLOS ONE. 2018 Aug 22;13(8):e0202734.

10. WHO The global prevalence of anemia in 2011. World Health Organization Geneva; 2015.

11. M. Alem, B. Enawgaw, A. Gelaw, T. Kena, M. Seid, and Y. Olkeba, "Prevalence of anemia and associated risk factors among pregnant women attending antenatal care in Azezo health center Gondar town,NorthwestEthiopia," Journalof InterdisciplinaryHistopathology,vol.1,no.3,pp.137-144, 2013.

12. Kebede A, Gerensea H, Amare F, Tesfay Y, Teklay G. The magnitude of anemia and associated factors among pregnant women attending public institutions of Shire Town, Shire, Tigray, Northern Ethiopia, 2018. BMC Research Notes. 2018 Dec 27]; 11(1). 
13. Befikadua Zekarias, Asrat Meleko*, Abdu Hayder, Abraham Nigatu and Tilahun Yetagessu Prevalence of Anemia and its Associated Factors among Pregnant Women Attending Antenatal Care (ANC) In Mizan Tepi University Teaching Hospital, South West Ethiopia Vol.11 No.5:529 2017.

14. Adesina O, Olubukola A, Odunayo A. Anemia in pregnancy at two levels of health care in Ibadan, south west Nigeria. Annals of African Medicine. 2011;10(4):272.

15. Ethiopia Demographic and Health Survey (EDHS) 2016.

16. Gebre A, Mulugeta A. Prevalence of Anemia and Associated Factors among Pregnant Women in North Western Zone of Tigray, Northern Ethiopia: A Cross-Sectional Study. Journal of Nutrition and Metabolism. 2015;2015:1-7.

17. Kenea A, Negash E, Bacha L, Wakgari N. Magnitude of Anemia and Associated Factors among Pregnant Women Attending Antenatal Care in Public Hospitals of Ilu Abba Bora Zone, South West Ethiopia: A Cross-Sectional Study. Anemia. 2018 Nov 12;2018:1-7.

18. Obse N, Mossie A, Gobena T. Magnitude Of Anemia And Associated Risk Factors Among Pregnant Women Attending Antenatal Care In Shalla Woreda, West Arsi Zone, Oromia Region, Ethiopia. 2013;23(2):9.

19. Igweonu OU, Onyeneho NG. Anemia in Pregnancy: Urban-Rural Comparison of Management and Prevention Among Women of Child-Bearing Age in Anambra State, Nigeria. Int Q Community Health Educ. 2019 Apr;39(3):155-61.

20. K.A.AleneandA.Mohamed Dohe,"Prevalence of Anemia and Associated Factors among Pregnant women in an urban area of Eastern Ethiopia,"Anemia,vol.2014,pp.1-7,. 2014;

21. S. Gies1, B. J. Brabin1,2, M. A. Yassin3 and L. E. Cuevas1. Comparison of screening methods for anaemia in pregnant women in Awassa, Ethiopia volume 8 no 4 pp 301-309 april 2012.

22. Hailu Jufar A. Prevalence of Anemia among Pregnant Women Attending Antenatal Care at Tikur Anbessa Specialized Hospital, Addis Ababa Ethiopia. Journal of Hematology \& Thrombo embolic diseases. 2013; 02(01).

23. Ayano B. Assessment of Prevalence and Risk Factors for Anemia Among Pregnant Mothers Attending Anc Clinic at Adama Hospital Medical Collage, Adama, Ethiopia, 2017. Journal of Gynecology and Obstetrics. 2018;6(3):31.

24. Berhe B, Mardu F, Legese H, Gebrewahd A, Gebremariam G, Tesfay K, et al. Prevalence of anemia and associated factors among pregnant women in Adigrat General Hospital, Tigrai, northern Ethiopia, 2018. BMC Research Notes. 2019 Dec;12(1).

25. Alem M, Enawgaw B, Gelaw A, Kenaw T, Seid M, Olkeba Y. Prevalence of Anemia and Associated Risk Factors among Pregnant Women Attending Antenatal Care in Azezo Health Center Gondar Town, Northwest Ethiopia. Vol. 1. 2013. 1 p.

26. S.Brooker,P.J. Hotez, and D.A.P.Bundy,"Hookworm-related anaemia among pregnant women: a systematic review," PLoS Neglected Tropical Diseases,vol.2,no.9,articlee291,2008.

27. D. H. Henry and J. A. Hoxie, "Hematologic manifestation of AIDS," in Hematology: Basic Principles and Practices, R. Hofman,E.Benz,S.Shattiletal.,Eds.,pp.2585-2628,Churchill Livingstone,NewYork,. 
2013;edition six.

28. Fekadu Beyene GD. Assessment of Knowledge of Pregnant Mothers on Maternal Nutrition and Associated Factors in Guto Gida Woreda, East Wollega Zone, Ethiopia. Journal of Nutrition \& Food Sciences. 2013]; 03(06).

\section{Figures}

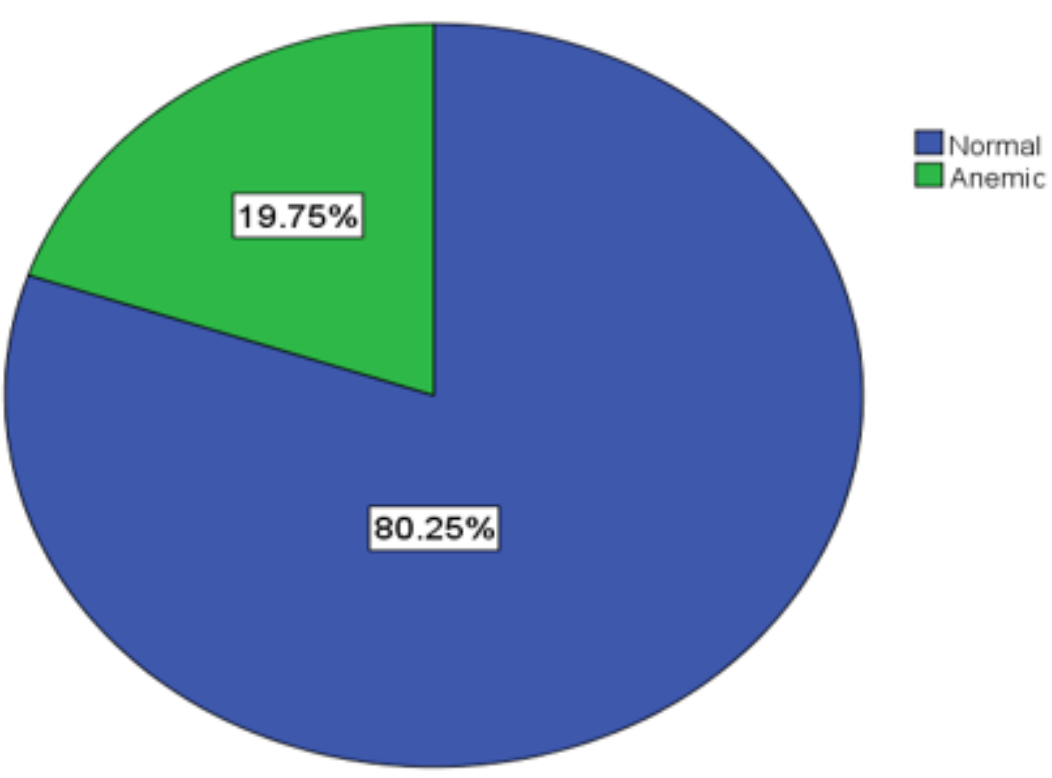

Figure 1

Magnitude of anemia among the study participants 